\title{
高度鼻出血に対する新しい非観血的止血法
}

\author{
辺土名 化・鈴木 政彦 ・小松崎 篤 \\ 村岡 秀樹*・合津 和央*
}

\section{A New Treatment for Severe Epistaxis}

\author{
Hitoshi Hentona, Masahiko Suzuki and Atsushi Komatsuzaki \\ (Tokyo Medical and Dental University) \\ Hideki Muraoka and Kazuo Gotsu \\ (Kawaguchi Kogyo General Hospital)
}

Patients with severe bleeding from the upper and posterior portions of the nasal cavity are generally treated by Bellocq tamponade, balloon tamponade or surgery, i,e, embolization or ligation of the artery. These procedures cause local pain, headache and nasal obstruction. We tried a new method of treatment in 31 patients with severe epistaxis using oxy-cellulose cotton. The bleeding was controlled adequately in 29 patients, some of whom had been treated by Bellocq tamponade in other hospitals and pleased to be free of the discomfort of their previous experiences.

This new method is summarized as follows:

1) It is mandatory to recognize the bleeding point, because oxy-cellulose cotton is to be packed at only one bleeding point in the nasal cavity.

2) Oxy-cellulose cotton is divided into small fragments, because the space around the bleeding point is usually narrow and deep within the nose. A piece of the divided contton is dipped in epinephrine or lidocaine solution before use because dry cotton sticks easily to normal nasal mucosa.

3) Referred pain is felt in the ear when the cotton is packed on the lateral wall of the inferior meatus, and in the forehead when it is packed in the meatus olfactorius.

4) This treatment never interferes with other treatments for severe epistaxis, and combined procedures with ribbon gauze, Bellocq tamponade, balloon tamponade, etc, can be used when needed.

5) Inserted cotton does not need to be removed, because it is absorbed in a few days.

Key words: new treatment, severe epistaxis, oxy-cellulose cotton

はじめに

一般に耳鼻咽喉科診療で経験する特発性鼻出 血症例は，多くの場合キーセルバッ八部位より のもので，止血は比較的容易である。しかし他
施設よりの紹介患者や救急外来を受診する患者 の場合は，止血が困難でベロックタンポンや止 血用バルーンが用いられていることが少なくな い.これらの処置を受けた患者は局所の疼痛や

東京医科歯科大学医学部耳鼻咽喉科学教室

* 川口工業総合病院耳鼻咽喉科 
頭痛，鼻閉，嬹下困難等の苦痛を余儀なくされ て扣り，我々はこのよらな苦痛を軽減させ，乙 かも効率よく止血させる方法を検討していた。 高度鼻出血症例を検討すると，外傷や腫瘍さら に出血性素因等を有する症例を除壮ば，入院を 要するよらな症例でも多くの場合止血点は鼻腔 内の 1 点のみである。そこで出血部位を十分に 確認して効率的に圧迫すれば止血処置として十 分であると考光, 出血部位へ少量のオキシセル 綿を直接指入する止血方法を試み，良好な結果 を得たので報告する。

\section{対象と方法}

対象は平成 2 年 1 月より平成 4 年 6 月までに, 川口工業総合病院耳鼻咽喉科で経験した鼻出血 症例166名(入院：31名, 外来：135名)のらち, 入院を要した高度出血症例である. 外傷後や術 後の鼻出血症例は含めなかった．また外来治療 のみで容易に止血した135名は法とんどがキー セルバッハよりの出血であり，今回は対象から 除外した。

方法は耳鼻咽喉科外来で広く使用されている オキシセル綿(酸化セルロース)を用いる止血法 であり，その具体的方法を以下に示した。

1）まず出血部位を鼻咽腔ファイバースコ ピー等で十分に確認する，鼻腔内の 1 点を圧迫 する方法であるため，その確認は必須である。 後述するように, 難治性出血症例の高頻度出血 部位は嗅裂, 中鼻道, 下鼻道側壁後端であり, その部位を中心に検索すると出血点の確認も容 易になる。

2）オキンセル綿を全体の10分の 1 程度, 短 冊状に縦に裂く（図 1)。このような形状の綿を 用いる目的は，下鼻道や嗅裂等の狭い部位に綿 を挿入するにはある程度の細さが必要なためで ある。

3 ）裂いたオキシセル綿を5000倍ボスミンま たは $4 \%$ キシロカインに浸す。あらかじめ綿を 湿らすことにより，狭い挿入部位での綿のすべ りのよさを確保する。オキシセル綿を乾燥した まま鼻腔内へ挿入すると, 鼻腔粘膜へ綿が付着
したり，挿入途中で綿がバラバラになったりし て，目的とする部位に十分に届かないことが多 い.

4）才キシセル綿を出血部位に摄子で挿入す る. 出血部位が下鼻道側壁後端の場合には，挿 入最後に摂子の先端で上外側方向へ強く圧迫す る. その時耳への放散痛が生じるが，その確認 が重要である。嗅裂では前頭部への放散痛が生 じる。

5 ）出血部位の厈迫が不十分の場合には，同

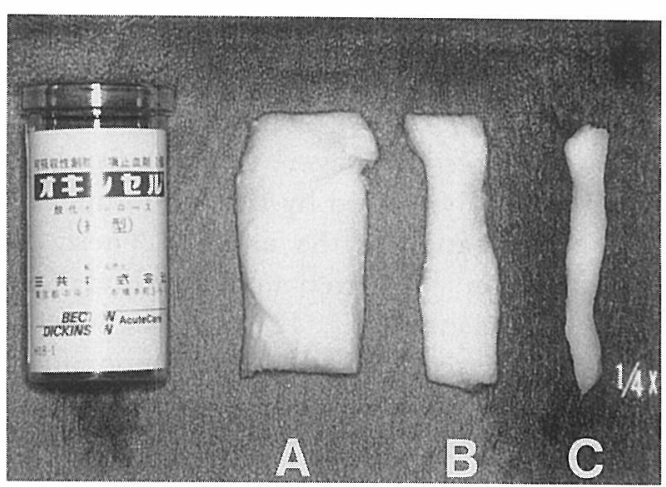

図 1 使用するオキシセル綿

A）使用前のオキシセル綿全体である．B）全体 の10分の 1 程度, 短冊状飞縦に裂いた綿である.

C） 5000 倍ボスミンまたは 4\%キシロカインで浸 した後の綿である。これを出血部位へ挿入する。

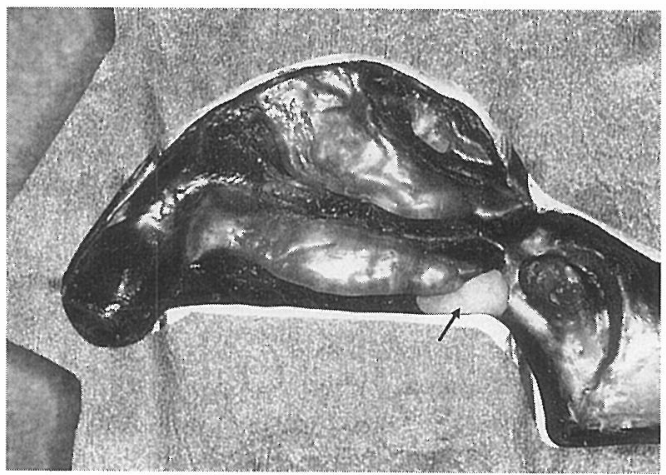

図 2 下鼾道後端へ挿入されたオキシセル綿(矢 印)を鼻腔模型を用いて示す，挿入最後に 綿を上外側方向へ強く圧迫すると耳への 放散痛が生じる. 
様な手技を再度繰り返すか, 補助圧迫のために ロールガーゼ等を用いる。しかしロールガーゼ は 30 $50 \mathrm{~cm}$ 程度の長さで十分であり，才キ シセル綿のみを圧迫するように挿入する。鼻腔 内に充満させるよらな長さのガーゼは必要ない。

6 ) 挿入後の才キシセル綿の状態を鼻腔模型 を使って示した(図 2).下鼻道後端では, 才キ シセル綿は下甲介後端と下鼻道側壁とで十分に 固定される。嗅裂では，鼻中隔とで鼻腔外側壁 とで十分に固定される.

7 ) 挿入されたオキシセル綿は 3 ～4 日で自 然吸收されるので，ベロックタンポンやロール ガーゼのよらに後日抜去する必要はない。その 後の挿入部は白苔で被われていることが多い.

\section{結果}

実際の症例を示した(図 3 ). 左下鼻道側壁後 端よりの出血症例であるが, 左図はオキシセル 綿挿入前で, 後鼻孔付近の凝血を認める. 右図 はオキシセル綿挿入後で, 下鼻道後端に綿の一 部を認めるにすぎない，補助圧迫のためのロー ルガーゼを併用しなかったため, 総鼻道は十分 飞開いて打り，通常通りの鼻呼吸が可能であっ
た。

入院症例を中心として, 受診方法, 出血部位, 治療成績等についてまとめた。

1. 年齢別患者数 (図 4 )

入院症例の年齢別患者数を示したが，比較参 考とするため外来症例についても提示した。 入 院症例は50歳代で一番多く, 中〜高年に多く認

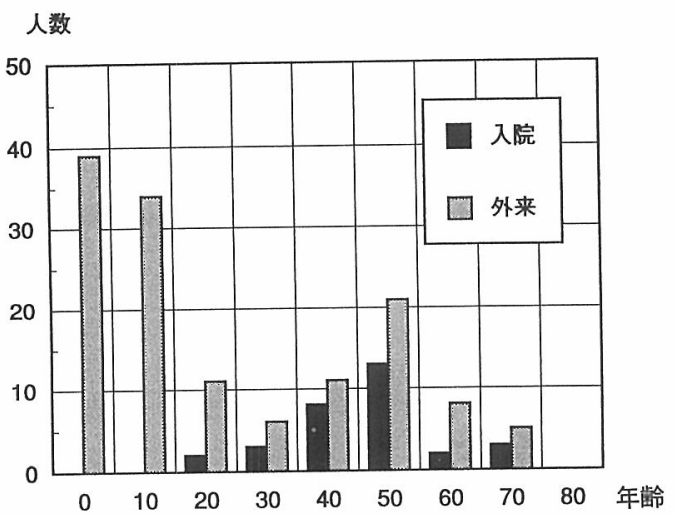

図 4 入院之外来症例の年龄別患者数 入院症例では 50 歳代が多く, 10歳代以下の若年者 は認めなかった。
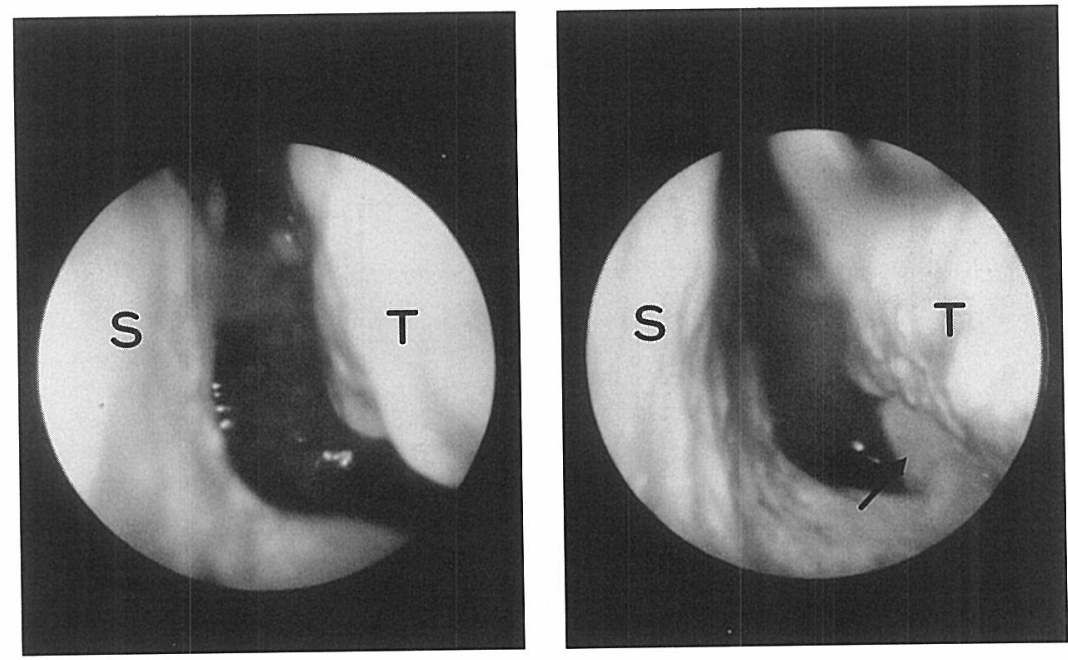

図 3 左下鼾道側壁後端より出血した症例 左図はオキシセル綿择入前で後鼻孔付近に凝血を認める.右図はオキシセル綿(矢 印) 挿入後で, 総鼻道は十分に開いている. $\mathrm{S}$ : 鼻中隔, $\mathrm{T}$ ：下甲介. 
められた．10歳代以下の入院はなかった．男性 21名，女性10名で，男性が約 3 分の 2 を占めた。 患側は右側12例, 左側19例であった. 外来症例 は10歳代以下が多く, 全症例の半数以上を示し た。

\section{2. 合併症 (図 5 )}

合併症は入院, 外来とも高血圧が多く, 特に 入院症例ではその傾向が著しかった，不整脈や 高脂血症等の他の循環器系疾患の合併も認めた。 鼻中隔弯曲, 鼻アレルギー, 副鼻腔炎等の鼻性 疾患の合併は, 入院症例では少なかったが, 外
来症例では10数\%に合併を認めた．妊娠は外来 の 2 症例で認めた。合併症を伴わない症例は入 院 7 例, 外来 98 例であり, 外来症例では合併症 なしが圧倒的に多かった。

\section{3. 入院症例の受診方法 (図 6 )}

近医耳鼻咽喉科よりの紹介は 9 例で，そのら ち 6 例はべロックタンポンが挿入されており， 3 例は鼻腔全体にガーゼが挿入されていた。そ の他の紹介では, 内科診察中に出血した症例が 2 例あった．救急で来院したのは14例で，その らち 3 例は近医耳鼻咽喉科で $1 \sim 2$ 日前に止血

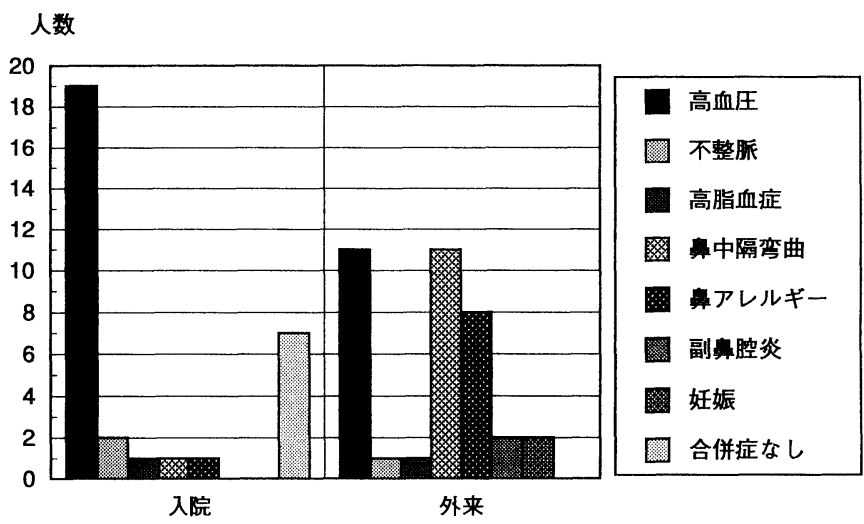

図 5 合併症の分類

入院, 外来症例とも高血圧を含めた循環器系の合併症が多かっ た. 合併症のなかった外来症例98例は図示を省略した.

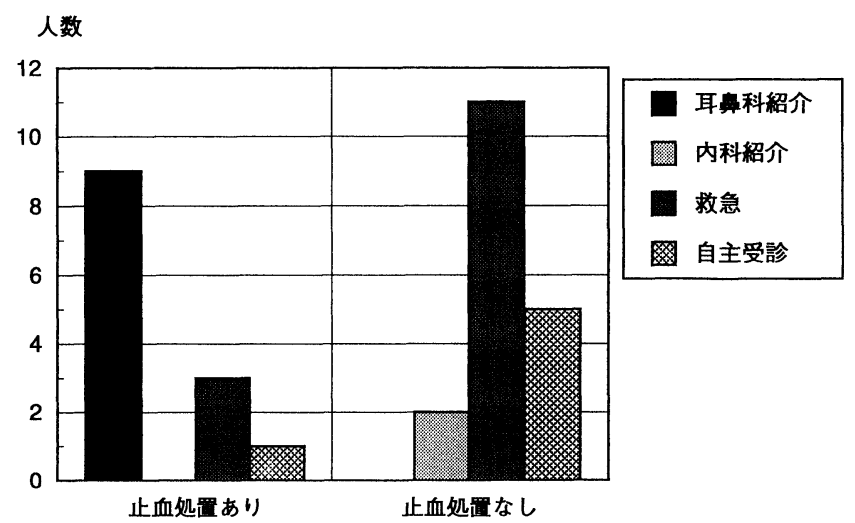

図 6 入院症例の受診方法

31例中13例は受診前すでに止血処置を受けており，ベロック タンポンやガーゼタンポンが挿入されていた. 
処置を受けて括り，ガーゼが鼻腔内へ挿入され ていた．残りの11例は新鮮例であった．診療時 間内に自己受診したのは 6 例で，1 例はすでに 近医耳鼻咽喉科で止血処置を受けて沶り，残り 5 例は新鮮例であった。以上をまとめると，何 らかの止血処置を受けた症例は31例中13例であ り，未治療症例は18例であった。

\section{4. 入院症例の出血部位(図 7 )}

各症例の出血部位を図示した. 1 個の黒丸が 1 症例の出血点である。一般に出血部位確認が 困難と言われている鼻腔後方や嗅裂よりの出血 が多かった，嗅裂上りの出血は 5 例で，前篩骨 動脈の関与と思われた。 中鼻道よりの出血は 4 例, 下鼻道側壁後端よりのものは13例であった. この部位の出血は外側後鼻動脈の関与と思われ た．受診前に止血処置を受けていた13症例は， 法とんどが以上の 3 部位よりの出血であった. 出血性鼻茸や鼻中隔の動脈性出血は確認が容易 でこれらは 9 例に認められた。
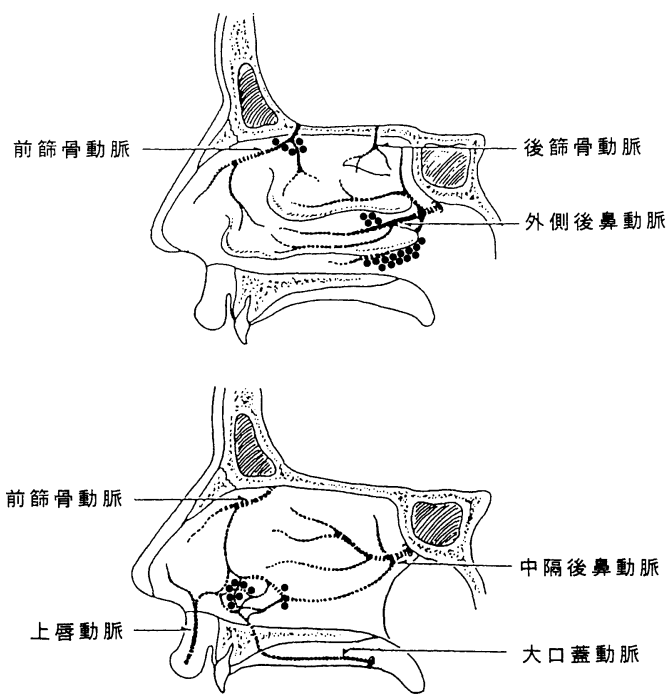

図 7 入院症例の出血部位（1症例の出血点は 1 個の黒丸で示した）

嗅裂, 中鼻道, 下鼻道側壁後端よりの出血が多く, 受診前に止血処置を受けた症例は汪とんどがこの 3 部位よりの出血であった. (廣戸幾一郎 : 19803) より改変)
5. 入院症例の治療方法 (図 8 )

治療としてオキシセル綿の単独使用で止血し たのは19例であった。そのらち下鼻道後端より の出血は11例, 中鼻道は 3 例, 嗅裂は 4 例, 鼻 中隔動脈性出血は 1 例であった。オキシセル綿 とロールガーゼを用いたのは，嗅裂より出血し た 1 例と止血用バルーンでは止血しなかった下 鼻道側壁後端の 1 例であった。鼻中隔動脈性出 血か出血性鼻茸の 6 例では主に電気凝固を用い, 補助としてロールガーゼを用いた．手術を施行 したのは 4 例であった．有茎性の出血性鼻茸症 例と鼻中隔弯曲症例は，受診当初より手術的治 療が必要と判断された。中鼻道より出血した 2 症例は, 才キシセル綿挿入後の $3 \sim 4$ 日間は止 血するが, その後に再出血を数度繰り返した. そのため Caldwell-Luc 法の応用にて鼻腔外側 壁を下鼻甲介とともに切除し，外側後鼻動脈の 断端を電気メスにて凝固止血し，ガーゼにて圧 迫止血した.

以上の上うに，当初上り手術的治療を目的と した 2 症例を除くと，29例のうち27例で非観血 的治療にて止血した。ささらに止血困難と言われ ている下鼻道側壁後端, 中鼻道, 嗅裂よりの出

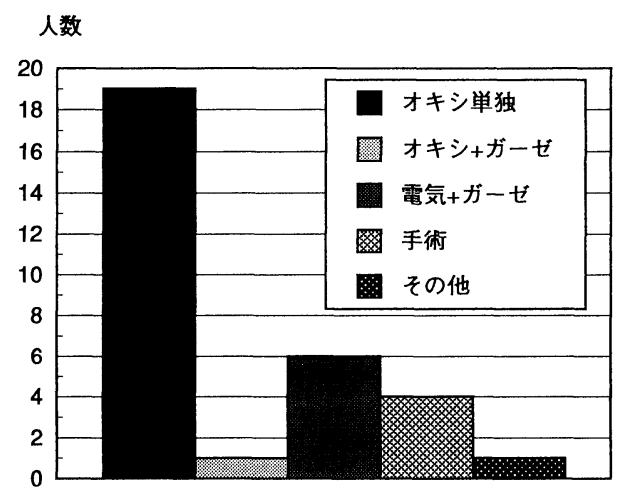

図 8 入院症例の治療方法 オキシセル綿単独で止血できたのは19例であ った．図中のその他は，止血用バルーンでは 止血せず，後にオキシセル綿とロールガーゼ を用いた例である。嗅裂，中鼻道，下鼻道後 端の出血に限定すると，22例中20例で本止血 法が有効であった。 
血に限定すると，本止血法による非観血的治療 といら点では，22例のうち20例で有効であり， ベロックタンポンや鼻腔ガーゼタンポン等を用 いずに止血できた。

受診前にすでに止血処置を受けていた13例は， 全例とも前治療法に比べて本止血法の方が苦痛 が少ないと述べていた.

\section{6. 入院期間（図 9 )}

全症例の平均入院期間は9.7日であった. 手 術を施行した 4 症例と本人の希望で21日以上入 院した 1 症例を除くと, その平均は7.4日であ った．全症例の出血部位別入院期間を比較する と, 中鼻道よりの出血症例が最も長く 14.5 日で, 鼻中隔動脈性出血が最も短かく7.3日であった。 手術症例を除くと, 鼻中隔動脈性出血は明らか に入院期間が短くなったが，他の 4 部位では注 とんど差がなく約 8 日であった。

7 . 経 過

各症例とも止血処置後約 2 年から 4 年が経過 しているが，1例を除いて再出血は認めない.

1 年後に再出血した症例は対側嗅裂よりの出血 であった。

\section{考察}

一般に鼻腔後部や嗅裂からの鼻出血は止血が 困難であり ${ }^{1)}$ 5)，入院を必要とする場合も少な
くない，入院を要する鼻出血症例を検討した本 邦報告(列6) 8)では，すでに近医にて止血処置を 受けながらも止血せず，紹介入院となった症例 が多数報告されている，我々の症例でも，31例 中13例の約 4 割強がすでに止血処置を受けてい た。このような症例は多くの場合，ベロックタ ンポンや鼻腔全体へのガーゼタンポンが挿入さ れて执り，苦痛を余儀なくされている．高度出 血症例ではまず止血させることが優先されるが, ベロックタンポン等の止血処置が有効であった かぞうか，またその止血法に至るまでの止血処 置が効率的であったかどらか，さらに患者に余 分な苦痛を与皃なかったかを考慮することは重 要である．最終的にはベロックタンポンを用い たり，観血的治療法が必要な症例もあるだろう が，その段階にいたるまでの非観血的止血法を 考直す必要があると思われる。

まず内田 ${ }^{9)}$ のよらに出血点の確認が一番大切 である，といら考方方が重要である，最近では ファイバースコピーの普及により出血点の確認 が容易になったと考兄られるが，入院を要する

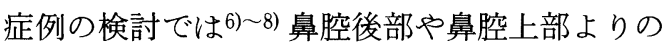
出血以外に, 出血点不明とする例が以外にも多 い. 外傷や腫瘍，さらに出血性素因を有する症 例を除けば，高度鼻出血症例でも多くの場合は

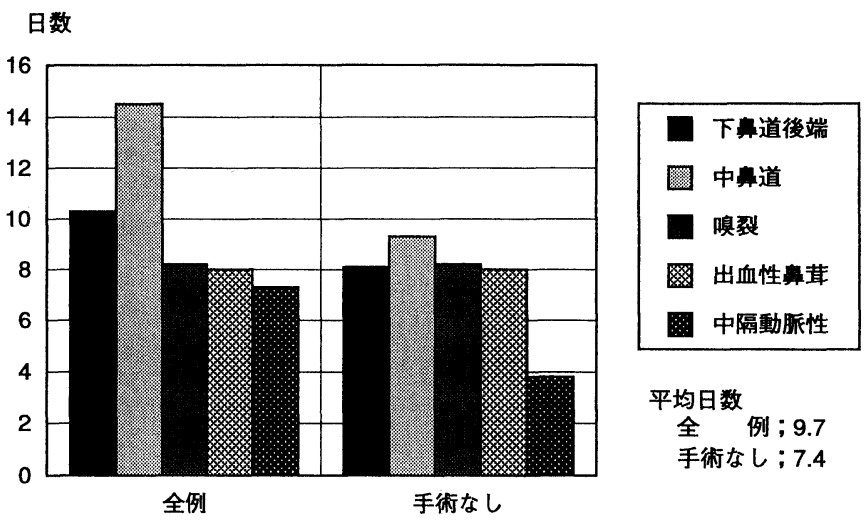

図 9 入院期間

全症例の平均入院期間は9.7日で，手術を施行しなかった症例 では平均7.4日であった。 
その出血点は鼻腔内の 1 点であり，その意味で は出血点確認に対して更なる検討が必要と考え られる．括とらく出血点不明とされた症例でも， 初期出血の時点あるいは入院後であっても，注 意深く検索すれば出血点が確認できたのではな いかと考光る．我々の症例のなかで，鼻中隔の 動脈性出血や出血性鼻茸の症例を除いた22症例 に限定すれば，出血部位は下鼻道側壁後端が一 番多く, 嗅裂, 中鼻道がそれに続いていた。こ の部位の支配血管は図 7 でも示したように，下 鼻道後端と中鼻道は外頸動脈系の外側後鼻動脈 で，嗅裂は内頸動脈系の前篩骨動脈である，後 篩骨動脈は前篩骨動脈に比べて細く，その支配 領域も狭いために鼻出血に関与することは少な いと言われている4)。このように鼻中隔を除く 鼻腔内の高頻度出血部位はある程度限定されて いるため, 出血点不明と思われる症例でも, 以 上の 3 領域に注目してファイバースコピー等で 検索すれば大抵の場合はその出血部位が確認で きると考兄られる．また止血処置がすでに行わ れたために受診時に出血していない症例でも， 同部位の血管怒張を確認できることが多い。こ れは内田 ${ }^{9)}$ も同様な所見を述べており，また特 に下鼻道側壁後端の出血に関しては Woodruff ${ }^{10)}$ の注目する The naso-nasopharyngeal pleuxs といら考え方と一致するものであった。

次に止血法の問題であるが，非観血的止血法 は種々の方法が試みられている.ガーゼタンポ ンやベロックタンポン以外では, Storz 社製や 高研製の止血用バルーンが知られ，最近では鼻 呼吸が可能なように工夫されたメ口セルも用い られている。しかし，これらのバルーンは嗅裂， 中鼻道や下鼻道側壁等の狭く, しかも複雑な構 造を有する部位へは直接圧迫ができず，鼻腔全 体へのガーゼ挿入を必要とする場合が多い，そ の意味では基本的にベロックタンポンと同様な 止血方法と考兄られ, 出血点の 1 点の久を圧迫 する我々の止血法とは根本的に異なっている. また鼻腔内へフィブリン糊を注入する方法 ${ }^{11)}$ や，外来に打ける凍結術12）も報告されている
が，これまでの報告例が少ないので追試が必要 であろう．以上のような非観血的止血法で止血 しない場合には観血的止血法が用いられ，その 効果はこれまでに多数報告されている．選択的 動脈塞栓術13) 17) では, Seldinger 法により主 に顎動脈の塞栓術が行われている。しかし，こ の方法は前篩骨動脈等の内頸動脈系の出血には 用いることができず，さらに耳鼻咽喉科医が単 独では行えないため施行可能な施設は打のずと 限定される．また，その合併症もいくつか報告 されており ${ }^{18)}$ ，施行に際して十分な注意が必要 である．支配動脈の結紮術では，Seiffert 法に よる顎動脈結禁術19)20) や, 前笁骨動脈結紮術20) が報告されている．この方法は再出血の場合に やり直せない欠点があり，また一方の動脈の閉 塞にて反対側からの血流増加といら報告21) ある，その意味では，止血法の最終段階で行う べきものであると考えられる。

今回我々が試みた止血法は出血点 1 点のみを 圧迫止血する方法であり，非観血的止血法のな かでも初期治療として用いることができる．止 血しなければ繰り返し施行可能であり, 補助圧 迫でガーゼ等を用いることも可能である。また， その他の非観血的あるいは観血的治療法の妨げ になることもない，今回経験した高度鼻出血症 例22例中20例に扮いて，オキシセル綿単独ある いは補助のロールガーゼの併用のみで完全止血 できたことは，非観血的止血方法として本邦の 止血効果は高かったと判断される.ささら今回 は検討しなかったが，外来症例135名のらち下 鼻道側壁後端よりの出血が 3 例あった。調査期 間後期の症例で，本手技に習熟した後であった ため外来治療のみで止血できた。 今後, 外来で の止血処置の第一選択枝としても本止血法を応 用できると考兄られる．また受診前に止血処置 を受けた症例は，ベロックタンポンやガーゼタ ンポンよりも本止血法のほらが楽であったと述 べており，本止血法の起点となった苦痛の軽減 といら目的でも効果はあった。ただ 2 例に拉い ては，本止血方法が無効で手術を余儀なくされ 
た．その原因は，出血点確認の甘さ，あるいは オキシセル綿挿入方法の稚拙さが考兄られる. 特に中鼻道は下鼻道後端と異なり鼻腔前方から 後方に向かって弯曲した走行を示し，オキシセ ル綿挿入時に下甲介前端の肩がじゃまとなる。 そのため出血部位へ綿を充分に挿入できなかっ た可能性があり，この部位の止血法は今後検討 を要する. 今回我々は出血性素因を有する症例 や外傷あるいは腫瘍症例を経験しなかったため, このような症例でも本止血法が有効かどらかは 判定でさない．しかし本止血法の基本が出血点 1 点のみを圧迫する方法であるため, 粘膜全体 よりの出血や鼻腔以外の出血で綿を挿入できな い場合は有効でないと推察される. また症例数 を重ねることにより，本止血法のみでは止血で きない症例も増えると推測されるが，そのよう な症例では他の止血法を用いる必要があると考 えられる。

\section{まとめ}

下鼻道後端や嗅裂よりの高度鼻出血症例に対 してベロックタンポン等が用いられるが，その 苦痛を軽減させ，さらに効率よく止血させるた め, オキシセル綿を出血点に直接挿入する方法 を試みた。 31例の入院症例のうち，本止血法を 22例に施行して20例で有効であった. 本止血法 ををとめると以下のようになる。

1 ）鼻腔内の 1 点を対象とするので, 出血点 の確認は必須である。

2 ) オキシセル綿挿入時, 耳や前頭部へ放散 する痛みの確認が重要である.

3）ロールガーゼ等による補助圧迫も可能で ある。

4）挿入されたオキシセル綿は $3 \sim 4$ 日で自 然吸収されるので，後日抜去する必要はない。

5 ) 従来のベロックタンポンや止血バルーン に比べて，患者の苦痛が少ない。

6 ）救急外来や他院より紹介の止血困難な症 例も対象となる. 止血方法の要領を得れば外来 のみで止血可能であり，入院は必ずしも必要で ない。
本論文の一部は第 1 回耳鼻咽喉科処置・手術手技 研究会(1994年, 東京)にて口演した.

\section{文献}

1）後藤敏郎, 白岩俊雄, 北村 武, 他 : 耳鼻咽搌 科学. $268 \sim 275$ 頁, 医学書院, 東京, 1968.

2）檜 学: 現代の耳鼻咽喉科学. 459 465頁, 金原出版，東京，1979。

3）廣戸幾一郎：小耳鼻咽喉科書. 41 42頁, 金芳 堂, 京都, 1980 .

4) Kerr AG and Groves J : Scott-Brown's Otolaryngology. Fifth edition. pp $272 \sim 282$, Butterworths, London, 1987.

5) Paparella MM and Shumrick DA : Otolaryngology. Second edition. pp $1994 \sim 2008$, Saunders, Philadelphia, 1980.

6）新川秀一, 綿貫幸三, 伊勢郁夫, 他 : 入院を必 要とした鼻出血患者の統計的観察.耳鼻 25： 181 186, 1979.

7）井上裕章, 朝郎真一郎 : 入院を要した鼻出血症 例 -10 年間の統計的観察一. 耳鼻 $28: 382 \sim$ 386, 1982

8）石井正則，鶴岡美果，実吉健策，他：鼻出血の 臨床統計 一とくに高路者の鼻出血について一. 耳展 35：45〜 51, 1992.

9) 内田 豊 : 鼻出血の救急処置. 耳鼻 $24: 298 \sim$ 302, 1978

10) Woodruff GH : Cardiovascular epistaxis and the naso-nasopharyngeal plexus. Laryngoscope $57: 1238 \sim 1247,1949$.

11）山本英一, 折田洋造：鼻出血飞対するフィブリ ン糊を用いた止血方法. 耳喉 56:167〜170, 1984.

12) Hicks JN and Norris JW : Office treatment by cryotherapy for severe posterior nasal epistaxis-update. Laryngoscope $93: 876 \sim 879$, 1983.

13）古内一郎，馬場廣太郎，馬場由子：鼻出血飞対 する新止血法. 耳喉 50 : 157 161, 1978 .

14) Merland JJ, Melki JP, Chiras J, et al : Place of embolization in the treatment of severe epistaxis. Laryngoscope $90: 1694 \sim 1704,1980$.

15）斎藤彰治, 堀内正敏, 新川 敦, 他：鼻腔後部 出血に対する選択的顎動脈塞栓術. 耳喉 56 ： 135〜142, 1984 
16）柳絵里子, 川上登史, 結縁晃治, 他：難治性鼻 出血に対する選択的塞栓術. 耳喉頭頸 62 : 1081 1084, 1990.

17）高橋志光, 加藤昭彦, 矢野原邦生, 他 : 難治性 鼻出血に対する超選択的動脈塞栓術. 耳鼻臨床 85 : 215 220, 1992.

18) Kirchner JA : Epistaxis. N Engl J Med 307 : $1126 \sim 1128,1982$.

19）池上彰博, 斎藤 彰, 岡本牧人, 他: 鼻出血に おケる顎動脈クリッピングの検討. 耳展 23 : $639 \sim 643,1980$.
20）朝涱真一郎, 永井知行, 伊藤正博 : 顎動脈, 前 篩骨動脈結禁を行った重篤な鼻出血症例. 耳鼻 $28: 370 \sim 375,1982$.

21) Shaheen $\mathrm{OH}:$ Arterial epistaxis. J Laryngol Otol $89: 17 \sim 34,1975$.

$\left.\begin{array}{l}\text { 原稿受付 : 平成 } 6 \text { 年 } 2 \text { 月 } 28 \text { 日 } \\ \text { 原稿採択 : 平成 } 6 \text { 年 } 4 \text { 月 } 12 \text { 日 } \\ \text { 別刷請求先 : 辺土名云 } \\ \text { 干 } 113 \text { 東京都文京区湯島 } 1-5-45 \\ \text { 東京医科歯科大学医学部耳鼻咽喉科学教室 }\end{array}\right)$ 